\title{
Simon Guggenheim
}

The Bulletin regrets to note the passing of Simon Guggenheim, a charter member of the Business Historical Society. He died in New York City on November 2, 1941.

Simon Guggenheim was a man of wide influence and reputation. He had a long and notable career in business. He served from 1907 to 1913 as United States Senator from Colorado. And he gave generously in support of philanthropic and educational causes and institutions. In 1925 he established, in memory of one of his sons, the John Simon Guggenheim Memorial Foundation. A man of broad culture and essentially an individualist, he stipulated that the Foundation should help scholars and artists in various fields, from all the Americas, and without restriction as to use of the funds granted. Under this endowment hundreds have been helped in the pursuit of their chosen fields, among them biologists, physicists, historians, artists, novelists, poets, and composers.

Simon Guggenheim was born in Philadelphia on December 30, 1867, the son of Meyer Guggenheim, who had come to America from Switzerland in 1847. Simon attended public schools in Philadelphia and, after graduation from high school, was sent to Europe to study. His special interest was languages; his study of Spanish, especially, helped to prepare him for his work in Mexican and South American mining.

On his return from study in Europe, he entered his family's mining business. In 1881 his father had invested some of the surplus which he had accumulated in his business as importer and wholesaler of lace, centered in Philadelphia, in a Colorado silverlead mining venture. Out of this successful investment had grown an interest in smelting and the entry of M. Guggenheim's Sons into western mining as the chief concern of the family. Simon settled in Pueblo in 1888. His particular work in his early years in business was to scout for ore for the Guggenheim Pueblo smeltery and in general to search for opportunities for the firm to expand, while his three older brothers who were active in the firm headed smelting operations, marketing, and finance.

Simon Guggenheim continued to represent the western interests 
of the family until 1913, long after his older brothers had come to attend chiefly to the New York end of their expanding silver and copper interests. $\mathrm{He}$ also served during that time as director of the Guggenheim Exploration Co., American Smelter Securities Co., American Export Co., and the American Smelting and Refining Co.

While he long represented the family interests in the field, he always participated in general administration. The brothers met frequently to discuss their problems and to decide upon policy, and each was allotted his specific tasks in the management of their business. As the youngest of the four brothers active in silver and copper interests, Simon had to take over more and more of general administrative responsibilities as his brothers retired. In 1919 he followed his brother Daniel as president of the American Smelting and Refining Co., which position he held until his death.

Thus Simon Guggenheim stood at the forefront in American and, indeed, world mining in its period of rapid growth. He early participated in promoting exploration and mining development from Utah to Chile and later on other continents. He helped materially to develop the use of low-grade ores and to make possible great advances in metallurgy. And he helped to build a great international mining and smelting organization, an integrated concern which under his administration became the largest of its kind in the world.

\section{Acquisition of Material from the Poor Publishing Company}

The old adage about an "ill wind" should have a qualifying phrase, at least as far as library acquisition is concerned. In order that libraries or historical institutions may benefit from others' adversities, it is essential that they have a friend in the neighborhood of the cyclone or other trouble-making wind. The Baker Library of the Harvard Graduate School of Business Administration was fortunate in having such a friend in Mr. Paul D. Babson.

The radical change in stock- and bond-market activities which 